\title{
Digital transformation in the advertising industry from a gender perspective: an analysis of the top agencies
}

\author{
Natalia Papí-Gálvez; Alejandra Hernández-Ruiz; Sonia López-Berna
}

Nota: Este artículo se puede leer en español en:

http://www.elprofesionaldelainformacion.com/contenidos/2020/may/papi-hernandez-lopez_es.pdf

How to cite this article:

Papí-Gálvez, Natalia; Hernández-Ruiz, Alejandra; López-Berna, Sonia (2020). “Digital transformation in the advertising industry from a gender perspective: an analysis of the top agencies". El profesional de la información, v. 29, n. 3, e290323.

https://doi.org/10.3145/epi.2020.may.23

Manuscript received on 15 October 2019 Accepted on 10 December 2019

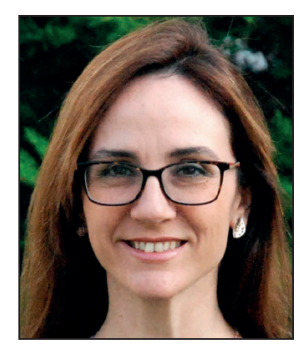

Natalia Papí-Gálvez $₫$ https://orcid.org/0000-0002-4871-1691

Universidad de Alicante, Facultad de Ciencias Económicas y Empresariales. Dpto. de Comunicación y Psicología Social 03690 Sant Vicent del Raspeig (Alicante), Spain natalia.p@ua.es

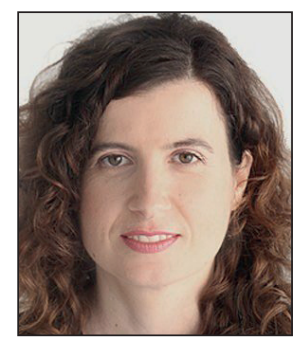
Alejandra Hernández-Ruiz https://orcid.org/0000-0002-9719-6534

Universidad de Alicante, Facultad de Ciencias Económicas y Empresariales. Dpto. de Comunicación y Psicología Social 03690 Sant Vicent del Raspeig (Alicante), Spain alejandra.hernandez@ua.es

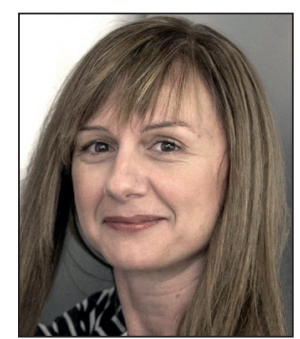

\author{
Sonia López-Berna \\ https://orcid.org/0000-0001-5959-8578 \\ Universidad de Alicante, Facultad de \\ Ciencias Económicas y Empresariales. \\ Dpto. de Comunicación y Psicología Social \\ 03690 Sant Vicent del Raspeig (Alicante), \\ Spain \\ sonia.lopez@ua.es
}

\begin{abstract}
This research departs from the strategies debated in an international framework for the achievement of gender equality through digitization and education, focusing in particular on the advertising industry. The advertising sector is immersed in a process of technological transformation that is precipitating substantial changes in companies, viz. advertising and media agencies, which are now demanding new professional profiles and adjusting traditional ones to the new media ecosystem. At the same time, and despite the feminization of the studies and workforce in this field, there is an unequal vertical and horizontal distribution by sex in Spanish agencies. Despite the previous evidence on the implications of the digital transformation for the work processes of agencies, no studies have explored this aspect from a gender perspective in Spain. In this context, this study investigates the roles and services of the leading agencies in the advertising industry more deeply, with the aim of evaluating both the digitization process and tasks close to $R+D+I$, and the roles of women therein. The results reveal parity in the sector and that the Digital and $R+D+I$ areas play a central role in the agencies. There are no significant differences by sex, either in Digital profiles or in the area related to $R+D+I$, but women occupy fewer positions on management boards and in the Creative area. In short, this study provides evidence regarding the professional reality in the advertising sector, in order to delineate actions in the educational field to respond to the needs of the economy and society in line with the gender equality project.
\end{abstract}

Funding

Work presented in the Strategic Communication Studies Group (E-COM) and in the Teaching Research Network Digital communication Technologies: Competencies and Expectations (ref. 4459) of the University of Alicante. 


\section{Keywords}

Gender studies; Gender; Segregation; Advertising; Professional skills; Digital communication; Research; Development; Innovation; Education; Technology.

\section{Introduction}

Spain ranks $11^{\text {th }}$ in the Digital Economy and Society Index (DESI) of 28 European countries (European Commission, 2019a). The positive progress observed in recent years is in line with the purposes set out in the Digital Agenda for Europe (European Commission, 2010). This index includes five dimensions, including human capital, being considered key to Europe's economic growth in the face of the great increase in demand for digital posts and those linked to R+D+I, expected ten years ago, by 2020. This dimension also recognizes two levels of competition by differentiating between skills that allow the use of the Internet from the most advanced skills required by companies. This latter category is particularly relevant to women.

In this regard, and although Spain does better on the Women in Digital (WiD) scoreboard compared with the DESI, achieving ninth place (European Commission, 2019b), the worst dimension is, again, that corresponding to the advanced level. It seems urgent to implement measures to encourage the choice of studies in the science, technology, engineering, and mathematics (STEM) field by young women, as already included in the Beijing Platform for Action (United Nations, 1995) almost 25 years ago, which aimed to

"Promote, together with literacy, life skills and scientific and technological knowledge" (United Nations, 1995, p. 49).

This continues to require enhancement of the

"access for and retention of girls and women in education and vocational training" (United Nations, 1995, p. 49),

including in the fields of information technology and high technology. These strategic objectives still apply today, in the light of data provided by the European Institute for Gender Equality (EIGE, 2017), which is responsible, among other functions, for conducting annual follow-up reports to determine the level of compliance with the goals marked by Beijing in Europe (EIGE, 2018).

However, this digital transformation currently not only involves purely technological sectors, but also affects the entire labor market (European Commission, 2018) and is accompanied by

“more diverse forms of work and new jobs, requiring new skills" (European Commission, 2018).

Moreover, such changes

"have the potential to contribute to increasing inequality and challenge time-honoured institutions" (European Commission, 2018),

including those relating to the broad communication sector.

With regard to the media, almost 25 years ago it was reported that, despite the increasing number of women in media-related careers, fewer of them held senior positions. To address these inequalities, strategic objective J.1. of the Beijing Platform for Action also proposed to promote

"education, training and employment to promote and ensure women's equal access to all areas and levels of the media" (United Nations, 1995, p. 150).

Education is thus conceived as an essential tool for achieving equality, although this may not always translate into greater achievements in the workplace. For this reason, evidence about professional reality is required to understand the phenomena that have occurred and articulate, if necessary, lines of action in the educational or professional field.

Consequently, against the background described above, this study focuses on the advertising sector to deepen understanding of the structures in advertising and media agencies and thereby evaluate the effect of the digital transformation from the gender perspective. In short, it tries to answer the following questions:

- How important are Digital and R+D+l roles and services?

- How many women occupy hybrid and technological roles?

- Do women occupy leadership positions in these areas?

And thereby,

- What are the possible implications of digital transformation for gender equality?

\subsection{Digital transformation and $R+D+l$ in the advertising industry and the educational context}

In 2018, advertising accounted for $1.06 \%$ of GDP (InfoAdex, 2019). Advertising is an important industry in economical terms, requiring appropriate training coverage. In particular, degrees in advertising and public relations aim to develop the basic competencies related to jobs in this sector. 
In the 2018-2019 academic year, enrollment in such degrees amounted to 14,026 students, with $73 \%$ being women on average (EducaBase, 2019), in comparison with $50 \%$ in the social sciences and law field. In addition, in the previous academic year, approximately 2,500 graduates entered the labor market, of whom $80 \%$ were women, versus $65 \%$ for the field of social sciences and law. These data contrast with the figures of $24 \%$ of female enrollments and $29 \%$ of female graduates for engineering and architecture degrees.
The advertising sector is immersed in a process of technological transformation that is precipitating substantial changes in advertising and media agencies, demanding new professional profiles and adjusting traditional ones to this new media ecosystem

The advertising sector is immersed in a process of technological transformation that is precipitating substantial changes in advertising and media agencies, requiring new professional profiles and the adjustment of traditional ones to this new media ecosystem (Castillo-Serna et al., 2012). Agencies have incorporated both community managers and content developers for brands (brand entertainment), creative programmers and front-end designers with knowledge of Internet tools, as well as account, media, and production professionals who are experts in new media, and digital planners, designers, and media negotiators (Corredor-Lanas; Farfán-Montero, 2010; Núñez; García; Abuín, 2013). Advertising agencies have made their processes more flexible and incorporated profiles based on this new technological culture, leading to a different professional culture (Kaufmann-Argueta, 2017). Media agencies are also adapting their activity and offering new services in which tasks related to research, development, and innovation play a central role (Papí-Gálvez, 2015; Perlado-Lamo-de-Espinosa; Papí-Gálvez; Bergaz-Portolés, 2019).

This digital transformation is altering the context in which advertising professionals work, not only because of the changes in the media ecosystem, but also because of consumer or user empowerment. In the field of hyperconnection, conversations thus result between brands and consumers, which explains the incorporation of customer relationship management (CRM) or the management of big data (Martín-Guart; Fernández-Cavia, 2014). On the one hand, the use of new technologies puts the focus on the consumer (Erevelles; Fukawa; Swayne, 2016), while on the other hand, processes become automated, for example in real-time bidding (Busch, 2016). Moreover, it is predicted that artificial intelligence will result in major changes (Li, 2019).

As a result of this phenomenon, there is growing interest in the incorporation of digital skills into the offering by universities, as demonstrated by the publication of the Libro blanco para el diseño de las titulaciones universitarias en el marco de la economía digital (White paper on the design of university degrees in the digital economy; Spanish Ministry of Industry, Energy and Tourism, 2015), containing more than 250 profiles that reflect the transversality of those associated with communication. In fact, other studies have also highlighted the hybridization of technological skills in the professional practice of journalists, thus affecting their training (López-García; Rodríguez-Vázquez; Pereira-Fariña, 2017). Digital skills are gaining ground in university studies, although according to the latest trends, their supply may still be insufficient (De-Salas-Nestares; Martínez-Sáez; Roca-Hueso, 2019; Ventura; Roca-Cuberes; Corral-Rodríguez, 2018). In this regard, other advertising-focused analyses have also demonstrated how job openings

“(...) increasingly require multidisciplinary aptitudes and skills” (Álvarez-Flores; Núñez-Gómez; Olivares-SantaMarina, 2018, p. 138),

to the point that the competences associated with technology (i.e., analytics, big data management, or programming) become the most widely demanded in the marketing and digital communication sector, according to industry reports (IAB-Spain, 2018).

\subsection{Women as advertising professionals}

Despite the high feminization of the related studies (EducaBase, 2019) and workforce (Benavides-Delgado et al., 2019), advertising shows characteristics similar to other industries. Previous research has revealed an uneven distribution both vertically and horizontally by sex in Spanish advertising agencies (García-González; Piñeiro-Otero, 2011; Martín-Llaguno, 2007; 2008; Moreno; Fuentes; Khalil, 2018; Pueyo-Ayhan, 2010; Soria-Ibáñez; Gómez-Nieto, 2017), although this is a widespread phenomenon (Arnberg; Svanlund, 2017; Crewe; Wang, 2018; Grow; Deng, 2014). This disparate sexual distribution is corroborated by the work of Hernández-Ruiz et al. (2012) based on expectations regarding the professional profiles of advertising and public relations students. That study demonstrated the identification of students according to "male" departments such as Production and Creative and "female" departments such as Accounts, Research, Planning, Public Relations, and Administration.

In the professional field, the First study on the advertising population in Spain (APG; Club de Creativos, 2019) revealed that, despite the gender balance in the sector, management in the advertising sector was predominantly male (with $76 \%$ being men). By departments, this gender gap in favor of men was further emphasized in Information Technology (80\% men). A greater number of men are also found in Creative (61\%). Women form the majority in Accounts (74\%). However, there are also some departments in which there is a better balance between the sexes. This is the case of New Business (57\% men, 43\% women) and Strategic Planning (43\% men, $57 \%$ women). 
In this context, digital transformation could act positively, as Mallia and Windels (2011) point out. In their study on Creative women, those authors concluded that the new professional culture, based on collaborative work in more specialized and diverse groups, favors the participation and recognition of women in the industry. However, although studies such as those of Kaufmann-Argueta (2017) address the implications of digital transformation on the work processes of agencies, no previous research has explored this from a gender perspective in Spain. Therefore, this study delves into the roles and services of the leading agencies in the advertising industry to evaluate the presence of digitization and tasks closely related to research, development, and innovation $(R+D+I)$, and the position of women therein. To do this, the professional profile of women in agencies is explored, paying special attention to roles and services. In particular, it aims to:

- Consider the presence of digital roles and services offered by advertising and media agencies in Spain and the roles closely related to $\mathrm{R}+\mathrm{D}+\mathrm{I}$.

- Compare the role of women in the Digital and R+D+l fields of agencies and contrast this with traditional areas of activity.

\section{Materials and methods}

A descriptive quantitative study of the top Spanish (or based in Spain) advertising and media agencies in the sector was planned. Companies found among the top 25 advertising agencies and top 25 media agencies based on the managed investment listed in InfoAdex (2018) and that also appeared in Scopen's most recent corporate directory (2019) were selected. This directory collects diverse information from 159 offices of a total of 116 companies, most of them located in Madrid and Barcelona. Finally, 39 agencies that met the criteria (Table 1) were selected, providing information on a total of 613 professionals: 400 from advertising agencies and 213 from media agencies, forming the nonstatistical sample of the study.

According to agency information, the size of the universe amounts to a total of 6288 employees, giving a margin of error (ME) of $3.8 \%$ assuming a $95 \%$ confidence level and maximum heterogeneity $(p=q=0.5)$. By agency type, the 400 advertising professionals would represent 3011 employees (ME 4.6\%) while the 213 media professionals would represent 3277 (ME 6.5\%).

Table 1. Analysis units (agencies) and count

\begin{tabular}{|c|c|c|c|c|c|}
\hline Advertising agency & Workforce & $\begin{array}{c}\text { No. of } \\
\text { observations }\end{array}$ & Media agency & Workforce & $\begin{array}{c}\text { No. of } \\
\text { observations }\end{array}$ \\
\hline \&Rosàs & 36 & 5 & AlmaMediaPlus & 16 & 7 \\
\hline Cheil & 107 & 7 & Arena Media & 201 & 15 \\
\hline Comunica $+A$ & 260 & 24 & Carat & 335 & 9 \\
\hline Contrapunto & 105 & 24 & Equmedia & 64 & 10 \\
\hline Darwin & 66 & 14 & Forward Media & 73 & 5 \\
\hline$D D B$ & 298 & 49 & Havas Media & 450 & 3 \\
\hline FCB\&Fire & 37 & 6 & IKI Media Communications & 39 & 7 \\
\hline Grey & 115 & 7 & Infinity & 67 & 12 \\
\hline Grow & 105 & 13 & Initiative & 124 & 23 \\
\hline Grupo Ogilvy & 396 & 26 & Mediacom & 301 & 11 \\
\hline Havas & 126 & 9 & Mindshare & 320 & 18 \\
\hline Leo Burnett & $\mathrm{N} / \mathrm{a}$ & 9 & $O M D$ & 310 & 10 \\
\hline McCann & 235 & 37 & PHD & 142 & 15 \\
\hline Pavlov & $\mathrm{N} / \mathrm{a}$ & 2 & Starcom & 168 & 18 \\
\hline Proximity & 114 & 17 & Wavemaker & 142 & 15 \\
\hline Publicis España & 151 & 15 & Ymedia Vizeum & 287 & 22 \\
\hline$S C P F$ & 72 & 10 & Zenith & 238 & 13 \\
\hline Shackleton & 219 & 29 & & & \\
\hline Sra. Rushmore & 102 & 31 & & & \\
\hline TBWA & 205 & 28 & & & \\
\hline Tiempo BBDO & 46 & 11 & & & \\
\hline$V M L Y \& R$ & 216 & 27 & & & \\
\hline \multirow[t]{2}{*}{ Subtotal } & 3,011 & 400 & Subtotal & 3,277 & 213 \\
\hline & & & Total & 6,288 & 613 \\
\hline
\end{tabular}

Source: InfoAdex (2018) and Scopen (2019)

To address the objectives of this work, the following information was selected and encoded from the most recent Scopen directory (2019): 
- basic company identification data (e.g., company type, name, city where the office is located, year of establishment, number of employees, and company size);

- management positions or professional staff (e.g., job title, gender, role name, and keywords in role); and

- services offered (e.g., type of services and corresponding agency).

A total of 23 variables were created and analyzed using SPSS software.

A variable was also incorporated to determine the visibility of the Digital component and activities that could be related to the $\mathrm{R}+\mathrm{D}+\mathrm{I}$ area in all roles, according to their name. This variable enables the detection of not only new profiles but also adapted traditional ones. The $\mathrm{R}+\mathrm{D}+\mathrm{I}$ area included all the most highly related positions, regardless of whether they were aimed at technological improvement or were oriented towards products, processes, organization, or marketing.

With regard to management and professional roles, in a first phase, the name of each position was recorded literally. Due to the observation of a wide variety of names associated with the same scope of work, in a second phase, the different positions were grouped according to a hierarchy, the areas detected according to the definition of the position, their relevance in terms of objectives, and the frequency observed in the resulting groups (Table 2).

Table 2. Role groups

\begin{tabular}{|c|c|}
\hline Group & Examples \\
\hline 1. CEO, President, General Director (level 1) & $\begin{array}{l}\text { Chief Executive Officer (CEO), President, President and Strategic Director, Executive Presi- } \\
\text { dent, Partner and General Director }\end{array}$ \\
\hline 2. Strategic management positions (level 1) & $\begin{array}{l}\text { Chief Strategy Officer (CSO), Chief Commercial Officer, Responsible for Marketing and } \\
\text { Communication, Chief Marketing Officer (CMO) }\end{array}$ \\
\hline $\begin{array}{l}\text { 3. Level } 1 \text { or } 2 \text { executive management positions } \\
\text { (depending on position } 1 \text { ) }\end{array}$ & $\begin{array}{l}\text { Chief Executive Officer (when CEO or declared as level 2), Chief Financial Officer (CFO), } \\
\text { Chief Operating Officer (COO) }\end{array}$ \\
\hline 4. Area: New Business & $\begin{array}{l}\text { New Business Director, New Business Development Director, Business Development Direc- } \\
\text { tor (level 2) }\end{array}$ \\
\hline 5. Area: Business & Business Director, Director of a Business Area \\
\hline 6. Area: Accounts & Account Group Director, Account Director, Account Manager \\
\hline 7. Area: Clients & Director of Client Services, General Director of Client Services \\
\hline 8. Area: Brands & $\begin{array}{l}\text { Brand and Communication Director, Brand Director, Brand and Digital Project Director, } \\
\text { Brand Leader, Brand Director and UX Strategy }\end{array}$ \\
\hline 9. Area: Strategy & Director of Strategy (level 2), Director of Strategic Planning, Director of Digital Strategy \\
\hline 10. Area: Production and Content & $\begin{array}{l}\text { Production Director, Graphic Production Director, Audiovisual Production Director, General } \\
\text { Director of Content Creation, Head of Content }\end{array}$ \\
\hline 11. Area: Media & $\begin{array}{l}\text { Media Director, Planning Director, Digital Trading Director, Head of Programming, Head of } \\
\text { Digital and Social Media, Trading Director, Audience and DMP Director, Planning \& Optimi- } \\
\text { zation Director, Director of Communication Planning and Analytics }\end{array}$ \\
\hline 12. Area: Creative & $\begin{array}{l}\text { Chief Creative Officer (CCO), General Creative Director Partner, Creative Director, Digital } \\
\text { Executive Creative Director, Technological Creative Director, Director of Creative and Digital } \\
\text { Innovation, Creative Director-Design. }\end{array}$ \\
\hline 13. Area: Digital (D) & $\begin{array}{l}\text { Digital General Director, Digital Development Director and Head of Digital, Digital Develop- } \\
\text { ment Director/UX, Chief Digital Officer, Head of Digital and Innovation, Head of Digital and } \\
\text { Direct Response Lead, Digital Partner, Chief Digital and Transformation Officer }\end{array}$ \\
\hline $\begin{array}{l}\text { 14. Research, Development, and Innovation } \\
(\mathrm{R}+\mathrm{D}+\mathrm{I})\end{array}$ & $\begin{array}{l}\text { Director of Research, Director of Data and CRM, Data for Business Design Director, Brand } \\
\text { Experience and Intelligence, Chief Data and Analytics Officer, Director of Analysis, Head } \\
\text { of Analytics and Insight, Chief Data and Technology Officer, Director of Technology and } \\
\text { Innovation, Chief Delivery Officer (Technology and Platforms) }\end{array}$ \\
\hline 15. Communication & $\begin{array}{l}\text { People and Corporate Communication Director, Director of Integrated Communication, } \\
\text { Director of Communication and External Relations, Director of Consulting, Director of } \\
\text { Communication and Public Relations, Director of Communication }\end{array}$ \\
\hline 16. Events & Director of Events \\
\hline 17. Retail & General Director of Retail Area \\
\hline 18. Others & (Other company positions not included in the previous categories). \\
\hline
\end{tabular}

Source: Based on Scopen (2019). Level: 1. Managerial position; 2. Other managerial/professional roles

Some of the services had to be grouped together to facilitate reading. In this case, the digital ones were also distinguished from the general ones. The digital ones included those specifically from this field of work [e.g., Search Engine Optimization (SEO), Search Engine Marketing (SEM), Data Mining, Analytics, and Social Media] as well as those that included the word "digital" in their definition even if they were generic (e.g., digital communication, digital marketing, digital production). 
The frequencies and contingency tables between the variables were obtained. The feminization index was calculated. This indicates the proportion of the populations by sex and, thereby, quantifies the female representation in a specific category. This reveals how many women there were per man in each analyzed category. The range of $40-60 \%$, as specified in the first additional provision of Spanish organic law 3/2007 of March 22 (Spain, 2007) was considered to describe effective equality between women and men, in order to delimit the "balanced composition."

Bivariate analyses were performed using Pearson's chi-square test to determine whether there were significant differences $(p \leq 0.05)$ by digital services and type of agency or by job profile and sex. In the latter case, New Business and Business were combined to achieve the minimum count required. The calculations were carried out using SPSS software.

\section{Analysis and results}

\subsection{Presence of Digital and $R+D+I$ roles and services}

The first columns of Table 3 show the number of professionals and hybrid roles. The Digital and R+D+I professionals, taken together, amounted to 50 (8\% of 613), greater than Media, Business and New Business, or Strategy. Of these positions, $38 \%$ were specialized in digital, and $62 \%$ in technology, research, analysis, or innovation.

Mixed profiles were also observed, bringing the number of professionals in the Digital and R+D+I group to 81 ( $13 \%$ of 613), ranking third after Creative and executive positions. When including these hybrid profiles, the distribution between Digital and R+D+I functions changed in favor of Digital ( $51 \%$ of 81 ). The Media area included the greater number of these profiles.

The next columns (zone 1 and 2) present the distribution of roles by agency type, incorporating the mixed profiles into the corresponding Digital and $\mathrm{R}+\mathrm{D}+\mathrm{I}$ areas. Digital was in fourth place, after Creative, executive positions, and Advertising Accounts. However, it was in fifth position in the media agencies, after executive positions, Clients, Media, and $\mathrm{R}+\mathrm{D}+\mathrm{I}$. The position of the $\mathrm{R}+\mathrm{D}+\mathrm{I}$ area differed considerably between agencies, but no significant differences were observed between the number of employees in Digital and $\mathrm{R}+\mathrm{D}+\mathrm{l}$ by type of agency (zone 1$)(p=0.825)$, or in management positions (zone 2) $(p=0.673)$. On the other hand, Digital and $R+D+I$ taken together revealed significant differences $(p=$ 0.036 ) by type of position (level 1 and 2 ) and by type of agency. There was a greater concentration of Digital and R+D+I managers in advertising agencies (69\%), as well as professionals in this group in media (56\%).

Table 3. Presence of Digital and $\mathrm{R}+\mathrm{D}+\mathrm{I}$ groups by type of agency and position

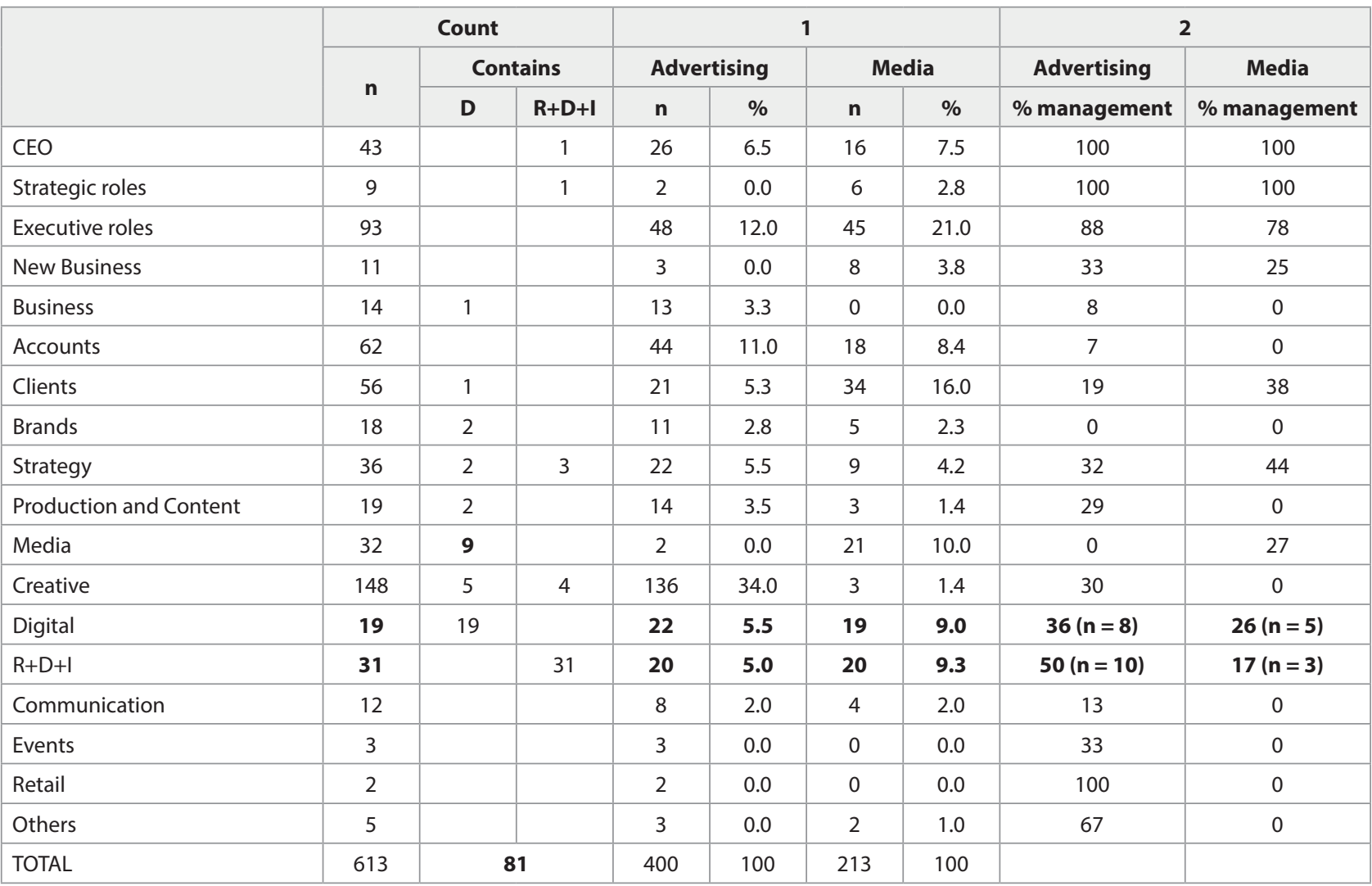

Note: $\mathrm{n}=$ count, $\mathrm{D}=$ Digital

Regarding services, $63 \%$ of the 588 records were generic, that is, not specifying whether they were digital. Advertising agencies had a higher concentration of such services (78\%). In contrast, half of the services offered by media agencies were digital (49\%), so the differences were statistically significant between the two types of agencies $(p<0.001)$. 


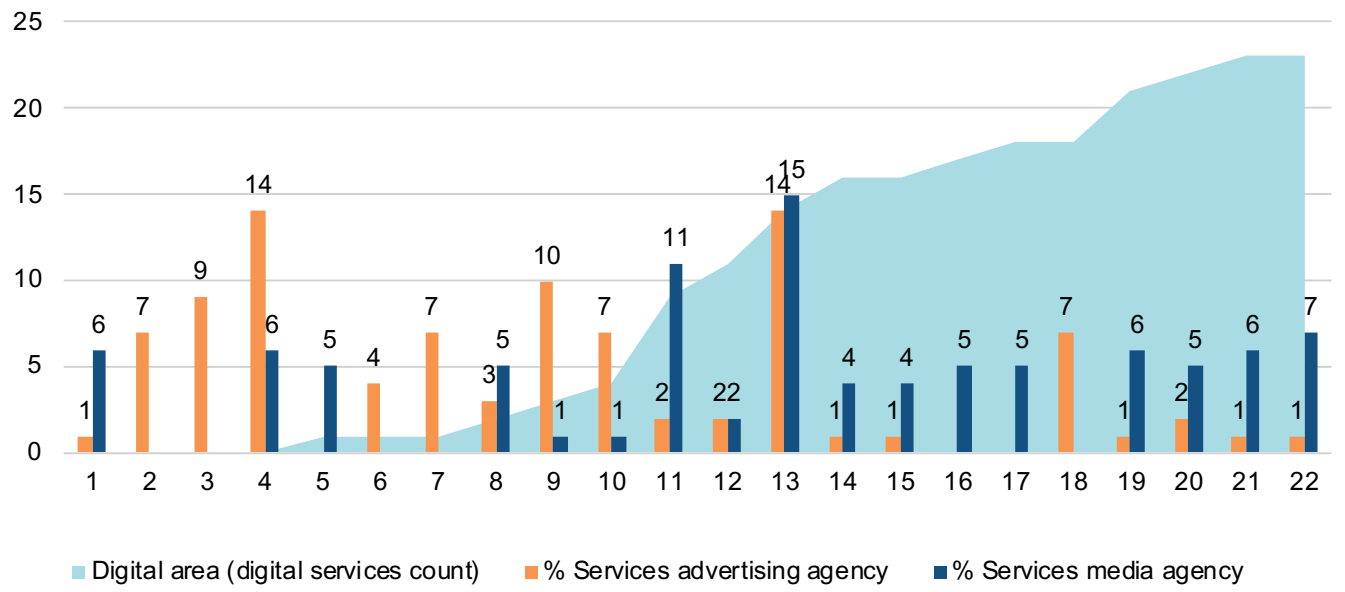

Figure 1. Declared services and the percentage thereof performed by the agency itself.

Labels: 1 . Consulting; 2 . Sales promotion; 3. Conventional advertising; 4 . Sponsorship/events/special actions; 5 . Creative; 6 . Communication and point of sale; 7. Direct marketing/telemarketing/relational; 8. Production and postproduction; 9 . Branding/design; 10 . Communication and public relations; 11. Research-strategic planning; 12 . Mobile marketing; 13. Planning-media management; 14 . Social media/social SEO; 15. Generation and dynamic content; 16. Affiliate marketing; 17. Digital marketing; 18 . Digital communication; 19 . Direct response/leads; 20. SEO/SEM; 21. Modeling/data mining; 22. Monitoring/analytics/reporting/research.

When delving into the declared digital services (Fig. 1), digital communication stood out in advertising agencies, not being present for media agencies. Affiliate and digital marketing were services offered by media agencies. A crossover was also observed in the services available by agency type. Advertising agencies offered Media services and media agencies Creative services, in contrast to the predominant functions and professional profile of each type of company. Furthermore, although Media services were outsourced (by $72 \%$ of advertising agencies), $93 \%$ of media agencies reported taking on Creative functions. In this regard, all the services declared by the media agencies were performed by the company itself (at percentages above $85 \%$ ), in contrast to the advertising agencies. Production and consulting services, along with media services, were among the most outsourced by the latter.

\subsection{The position of women in agencies}

Regarding the sex composition of the agencies analyzed, a greater number of men (59\%) than women (41\%) was observed (Table 4). The feminization index of the entire sample was calculated as 0.71 . This proportion lies within the established range (40-60\%) (Fig. 2). In contrast, the presence of women was twice that of men in the following categories (in order): New Business and Business, Brands, Clients, Accounts, and Media. The media agencies lay in the "balanced composition" range in general, and the Strategy and Communication profiles in particular. However, the other categories, especially management positions and Creative, fell below this balanced range.

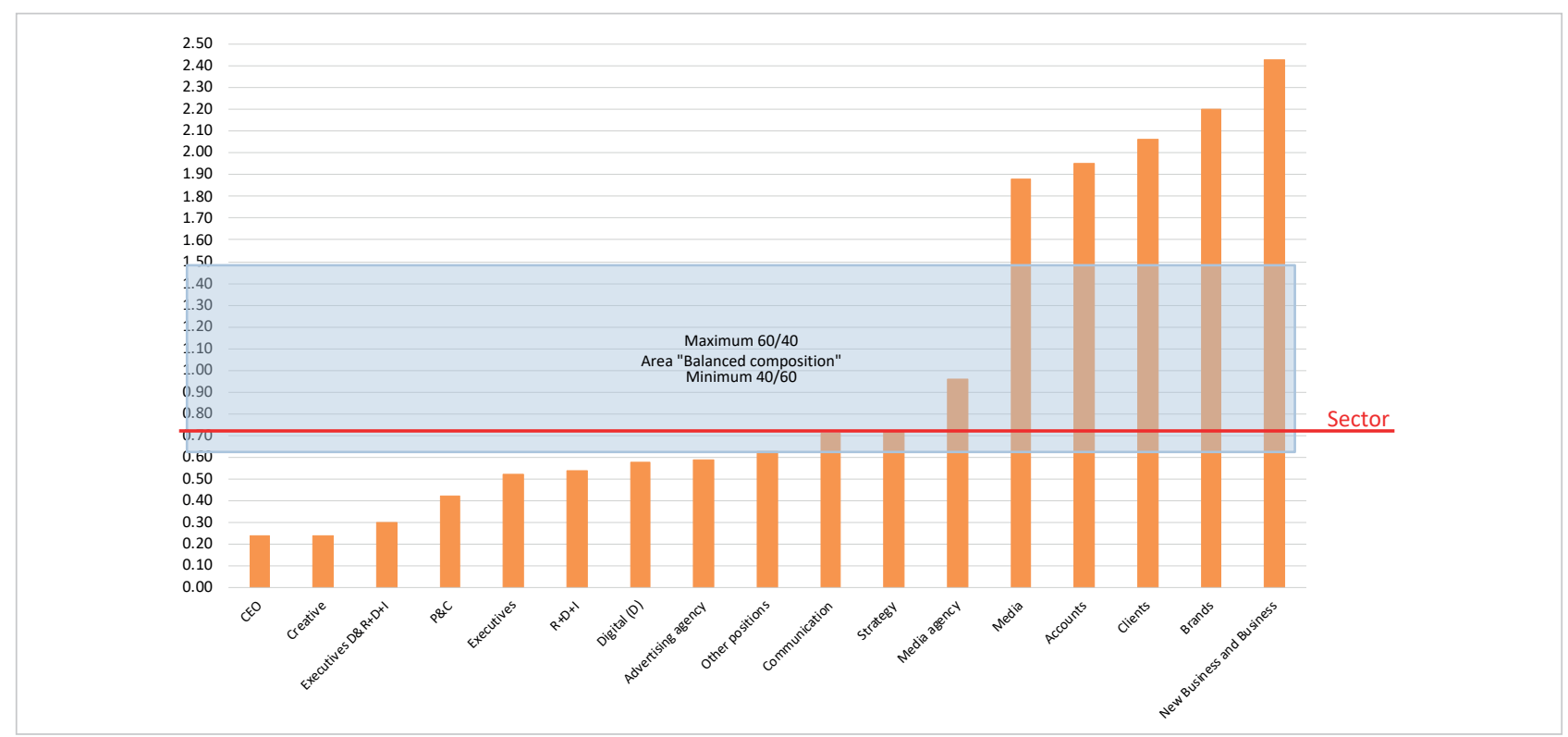

Figure 2. Feminization index by category

* feminization index $=$ women $/$ men 
Thus, significant differences were found in the distribution by sex and type of agency (Table 4). Although there were more women in advertising agencies, they represented a higher proportion in media agencies. More men held senior management positions. For the other positions, no statistically significant differences were observed.

Regarding the areas of work, statistically significant differences emerged in favor of women in New Business and Business, Accounts, Clients, Brands, and Media, in line with the feminization index. However, with the exception of management, the only masculinized area with statistically significant differences was Creative. The other areas did not show differences by sex, and neither did the Digital or technological, research, and innovation profiles.

Table 4. Frequency, feminization index, and Chi-square test

\begin{tabular}{|c|c|c|c|c|c|c|}
\hline & \multicolumn{2}{|c|}{ Women } & \multicolumn{2}{|c|}{ Men } & \multirow{2}{*}{$\begin{array}{c}\text { Feminization } \\
\text { index }\end{array}$} & \multirow{2}{*}{$p<$} \\
\hline & $n$ & $\%$ & $n$ & $\%$ & & \\
\hline Sample & 254 & 41 & 359 & 59 & 0.71 & \\
\hline \multicolumn{7}{|l|}{ Type of agency } \\
\hline Advertising agency & 149 & 59 & 251 & 70 & 0.59 & \multirow{2}{*}{0.01} \\
\hline Media agency & 104 & 41 & 108 & 30 & 0.96 & \\
\hline \multicolumn{7}{|l|}{ Type of role } \\
\hline Executives & 84 & 33 & 161 & 45 & 0.52 & 0.01 \\
\hline \multicolumn{7}{|l|}{ Role } \\
\hline CEO & 8 & 3 & 34 & 10 & 0.24 & 0.01 \\
\hline Other positions & 39 & 15 & 62 & 17 & 0.63 & NS \\
\hline New Business and Business & 17 & 7 & 7 & 2 & 2.43 & 0.01 \\
\hline Accounts & 41 & 16 & 21 & 16 & 1.95 & 0.001 \\
\hline Clients & 37 & 15 & 18 & 5 & 2.06 & 0.001 \\
\hline Brands & 11 & 4 & 5 & 1 & 2.20 & 0.05 \\
\hline Strategy & 13 & 5 & 18 & 5 & 0.72 & NS \\
\hline$P \& C$ & 5 & 2 & 12 & 3 & 0.42 & NS \\
\hline Media & 15 & 6 & 8 & 2 & 1.88 & 0.05 \\
\hline Creative & 27 & 11 & 112 & 31 & 0.24 & 0.001 \\
\hline Digital (D) & 15 & 6 & 26 & 7 & 0.58 & NS \\
\hline$R+D+I$ & 14 & 6 & 26 & 7 & 0.54 & NS \\
\hline Communication & $(5$ & 2 & 7 & 2 & 0.71 & NS \\
\hline \multicolumn{7}{|c|}{ Type of position in Digital and $R+D+I(n=81)$} \\
\hline Executives & 6 & 21 & 20 & 39 & 0.30 & NS \\
\hline
\end{tabular}

Note: The test is not significant when $p>0.05$

\section{Discussion and Conclusions}

This study delves into observations from a gender perspective of the workforce and services of the main advertising and media agencies, paying special attention to Digital profiles and functions related to $R+D+l$. To do this, it first compares the number of professionals specialized in these functions with those in other areas and quantifies the Digital services offered. Secondly, it delves into the gender distribution of such profiles and those in traditional work settings. These analyses provide conclusive results, focused on information declared by the agencies themselves, the implications of which depict a framework for action that is both interdisciplinary as well as novel.

The approach applied constitutes one of the main strengths of the study, enabling the research to offer the first results on the effects of the digital transformation on equal opportunities between women and men in the advertising industry. The limitations of this work stem from the use of information declared by agencies, making it difficult to standardize data and, in some cases, leading to information gaps. However, it also provides a qualitative component in two senses. On the one hand, it reflects the agencies' responses to the set of data requested by the source and, as a consequence, analyzes the reality as presented by the companies themselves. On the other, it manages to capture the peculiarities of each agency through, for example, the diversity in the names of the positions, a consequence of the blurred borders detected between some areas, and some of their services.

The Digital and $R+D+I$ areas occupy a central position in the agencies. The number of professionals working in this group of activities, taken together, even exceeds those working in the areas that make up the core activities of media agencies (Media and Clients) 
Therefore, according to the results, the Digital and $\mathrm{R}+\mathrm{D}+\mathrm{I}$ areas play a central role in the agencies. Indeed, in comparative terms, this group of activities does not rank at the bottom of the observed work areas, thus its functions cannot be considered to be marginal or accidental. In fact, ignoring the board of directors, the combined number of professionals working in this group even exceeds those in the areas that make up the core activities of media agencies (Media and Clients). In the case of advertising agencies, the number of professionals in these profiles is less than in the main area (Creative) as well as Accounts. Overall, no differences are observed in the weight of the Digital and R+D+I group by type of agency, although other peculiarities are noteworthy.

Leading media agencies offer significantly more digital services than advertising agencies. In fact, in the media area, more hybrid profiles are detected, albeit with fewer managers located in the Digital and R+D+I group. When comparing services by type of agency, the changes that have occurred in these companies as a result of the digital transformation emerge, along the same lines as other reports (Scopen, 2018): although media agencies continue to focus their talent on Research and Planning, they also incorporate many other digital profiles, in some cases even becoming specialized agencies. An expansion of functions is also observed towards services typically offered by advertising agencies. On the other hand, advertising agencies show a high degree of concentration in Creative areas, and although they also offer Media services, these are carried out by another company.

Regarding the feminization of the sector, previous evidence (Benavides-Delgado et al., 2019; APG; Club de Creativos, 2019; Martín-Llaguno, 2007; 2008) confirms a parity in the sex distribution, as corroborated by the results of this study. Thus, despite the fact that a grea-

Leading media agencies offer significantly more digital services than advertising agencies ter number of men (59\%) than women (41\%) were detected in the sample, the results allow us to confirm a balanced composition in the terms defined by Organic law 3/2007 of March 22 for effective equality between women and men.

However, in this context, vertical and horizontal segregation are still present in advertising companies, as also shown by other cited studies. Women predominantly occupy fewer positions in the management team and Creative area. However, they are found to a greater extent in Business and New Business, Accounts, Brands, Clients, and Media. Their presence is also greater in media agencies, although without significant differences by sex in either Digital or R+D+I profiles, nor in their management positions. Considering the high degree of feminization in advertising and public relations degrees, greater female representation could be expected in all categories, even if such differences do not reach statistical significance.

There are several possible explanations for this lack of significance. Firstly, as Mallia and Windels (2011) pointed out, the digital revolution is accompanied by a change in processes that favors the participation of women. Secondly, although it was not possible to consider the age of the professionals who join such teams, the need to recruit talent could favor hiring of young people and, therefore, create less hierarchical or professional environments with other types of conditions, as reported by authors focused on the millennial generation ( $\mathbf{N g}$; Parry, 2016). Third, it could also be explained by the type of position, given that these profiles are less present in managerial positions. The analyzed positions are relevant enough to have been selected by the agencies themselves, for which a minimum of experience in the sector is assumed, which would minimize the mentioned effect of age and cause the emergence of vertical segregation by gender.

In this regard, according to data provided by the APG and Club de Creativos (2019) study, management positions are occupied by people over 40 who have been in the sector for more than 15 years. The percentage of women in the advertising industry decreases drastically for this age group, dropping from $37 \%$ in the range of $30-40$ years (versus $36 \%$ of men) to $25 \%$ (versus $42 \%$ of men). The similarity found in the immediately lower age range is diluted at older ages, suggesting the effect described as a "scissor graph" in other studies (e.g., Puy-Rodríguez, 2017).

Thus, more women than men leave the profession around the age of 40 , a fact that could be due to the search for reconciliation between personal and professional life in the face of the harsh demands and time requirements of the advertising profession. This could also be because women decide to become mothers. Currently in Spain the average age at which women have children is 32 years in general (National Statistics Institute, INE, 2019a) and between 35 and 39 years for those with higher educational levels (INE, 2019b) -recalling that the percentage of women with children in the advertising industry is especially low (Martín-Llaguno, 2008)- or because the two most feminized departments, Accounts (> 70\% women) and Strategic Planning (>50\%) (APG; c de c, 2019), are in turn those with the highest turnover in the agencies, presumably due to the high level of work stress (Martín-Llaguno; Beléndez-Vázquez; Hernández-Ruiz, 2007).

In any case, it is necessary to continue observing this phenomenon in future research because, according to trends in communication, particularly focused on technological innovations, the tasks related to the Digital and R+D+I group could continue to gain ground. Thus, although the communication dimension is essential to build relevant relationships with the public (Kumar; Gupta, 2016), an increase in professionals trained in science and engineering in the agencies is predicted. In fact, the lack of significant differences between women and men in these new areas of work, despite the strong feminization of university studies in

Vertical and horizontal segregation is still present in advertising companies 
advertising and public relations, could be due to the fact that agencies prefer to fill some of these new positions with graduates from the pure sciences or engineering, who provide competences that are complementary to those currently developed in communication degrees. Engineering studies at universities are strongly masculinized, so if an upward trend of new hires with markedly technological profiles is detected, the gap between women and men could increase, unless communication studies manage to offer hybrid programs that prepare professionals sufficiently in the skills demanded by the industry, thus opening a route to achieve gender equality in future generations. In such work, building bridges between universities and companies is key. In addition to talent training, universities can contribute their $R+D+I$ to the sector via different knowledge transfer formulas, thereby guaranteeing the opportunity for postgraduate programs leading to a doctorate and thesis. Industry-oriented doctoral degrees could be a starting point.

This study presents a vision of the large agencies, focusing in particular on the presence of digitization and tasks close to $R+D+I$. However, it is necessary not to lose sight of the digital transformation of small and medium-sized enterprises (SMEs), which represent the bulk of the advertising sector in Spain (Benavides-Delgado et al., 2019), and its geographical area. In this regard, most of the agencies consulted in the First study of the advertising population of Spain (APG; Club de Creativos, 2019) were small or medium-sized, and concentrated in Madrid. According to this report, departments related to information technology are strongly masculinized ( $80 \%$ male). On the other hand, as an example of territorial diversity, in the case of the Valencian Community, it is observed that, in parallel with the integration of new services and in line with the trend observed at the national level (Benavides-Delgado et al., 2019), the digital profiles necessary to satisfy such demands are being introduced but have not yet been filled by pure science or engineering graduates (Breva-Franch; Mut-Camacho; Miquel-Segarra, 2019), something that, as Kaufmann-Argueta (2017) points out, has already been detected in larger agencies. Something similar is observed in the Basque Country. Although new positions associated with the management of digital media may arise, the most valued competences continue to be those of Creative and Strategic Planning, without neglecting training in digital contexts (Monge-Benito; Etxebarria-Gangoiti, 2017).

In closing, this research focuses on the advertising industry and some of the strategies debated in the international framework for gender equality. In particular, it considers the occupation of decision-making positions by women, especially in the communication sector, and underlines both the contribution from education, mainly in the STEM field, and the opportunity to strengthen the university-business relationship to identify ways to collaborate for the benefit of training programs, their graduates, and society. Currently, the services oriented towards digital communication and applications of advertising technology require professionals who understand this new model and who combine, to a greater or lesser extent, competences from different disciplines and fields. The findings of this study point out that, although such structures are changing, there are no differences by sex in these functions despite the strong presence of women in advertising and public relations. It is, therefore, necessary to ask how digital transformation will affect the equality of opportunities between women and men, or if it will be sufficient to guide university communication studies towards such new requirements.

The application of the gender perspective provides this research with a necessary critical vision, without abandoning the constructive approach that complements the exploration and identification of new professional profiles and their corresponding competences, with the intention of stimulating future paths of inquiry in advertising. Moreover, this tries to open an alternative route to the dominant discourse on the underrepresentation of women in university science and engineering degrees, which mainly focuses on the requirement to promote STEM skills among the female population, which remains apparently far from the social sciences. This study, on the other hand, maintains that the advertising industry provides a relevant and necessary observational framework to understand how such competencies affect not only the profession but in particular the equality between women and men.

In short, such a focus on the observation of Digital or research, development, and innovation profiles in advertising and media agencies from a gender perspective enables better understanding of both the digital transformation processes in the communication professions and the employment opportunities and professional development in agencies of the future, based on which training programs that respond to the needs of the economy and society can be designed in accordance with the gender equality project.

\section{References}

Álvarez-Flores, Erika-Patricia; Núñez-Gómez, Patricia; Olivares-Santamarina, José P. (2018). “Perfiles profesionales y salidas laborales para graduados en Publicidad y Relaciones públicas: de la especialización a la hibridación". El profesional de la información, v. 27, n. 1, pp. 136-147.

https://doi.org/10.3145/epi.2018.ene.13 
APG; Club de Creativos (2019). I Estudio de la población publicitaria española.

http://bit.ly/2mbUX4R

Arnberg, Klara; Svanlund, Jonatan (2017). "Mad women: Gendered divisions in the Swedish advertising industry, 1930-2012". Business history, v. 59, n. 2, pp. 268-291.

https://doi.org/10.1080/00076791.2016.1182158

Benavides-Delgado, Juan; Alameda, David; Fernández-Blanco, Elena; López-de-Agulleta-Clemente, Carmen (2019). Observatorio de la publicidad en España. Asociación Española de Anunciantes.

http://bit.ly/2q3bFoW

Breva-Franch, Eva; Mut-Camacho, Magdalena; Miquel-Segarra, Susana (2019). "La digitalización y los perfiles profesionales". En: González-Oñate, Cristina (coord.). El negocio publicitario en la sociedad digital de la Comunidad Valenciana. Barcelona: Editorial UOC, pp. 67-88. ISBN: 9788491804307

Busch, Oliver (2016). "The programmatic advertising principle". In: Busch, Oliver (ed.). Programmatic advertising. The successful transformation to automated, data-driven marketing in real time. Springer, Cham, pp. 3-15. ISBN: 9783319 250236 https://doi.org/10.1007/978-3-319-25023-6_1

Castillo-Serna, Conrado; Mosqueda, María-Laura; Vega, María; Pérez, Nagi; Fernández, Daniel (2012). Perfiles profesionales más demandados en el ámbito de los contenidos digitales en España 2012-2017. Profesionales TIC 2011. Madrid: FTI - Ametic.

http://bit.ly/2oM64NH

Comisión Europea (2010). Comunicación de la Comisión al Parlamento Europeo, al Consejo, al Comité Económico y Social Europeo y al Comité de las Regiones. Una Agencia Digital para Europa, 19 mayo.

https://bit.ly/2OLsuy1

Corredor-Lanas, Patricia; Farfán-Montero, Juana (2010). “Demandas y formación: Nuevos perfiles profesionales para la publicidad en España". Pensar la publicidad, v. 4, n. 1, pp. 97-116.

https://revistas.ucm.es/index.php/PEPU/article/view/PEPU1010120097A

Crewe, Louise; Wang, Annie (2018). "Gender inequalities in the city of London advertising industry". Environment and planning A: Economy and space, v. 50, n. 3, pp. 671-688.

https://doi.org/10.1177/0308518X17749731

De-Salas-Nestares, Isabel; Martínez-Sáez, José; Roca-Hueso, Víctor (2019). “Los nuevos perfiles profesionales como elemento transformador de la industria publicitaria". Revista mediterránea de comunicación, v. 10, n. 2, pp. 11-28.

https://doi.org/10.14198/MEDCOM2019.10.2.16

EducaBase (2019). Enseñanzas universitarias. Estadística de estudiantes desde el curso 2015/2016.

https://bit.ly/2nBMUP8

EIGE (2017). Igualdad de género y digitalización en la Unión Europea. European Institute for Gender Equality. ISBN: 978 9294823915

https://doi.org/10.2839/380846

EIGE (2018). Study and work in the EU: set apart by gender review of the implementation of the Beijing platform for action in the EU member states. European Institute for Gender Equality.

https://eige.europa.eu/publications/study-and-work-eu-set-apart-gender-report

Erevelles, Sunil; Fukawa, Nobuyuki; Swayne, Linda (2016). "Big data consumer analytics and the transformation of marketing". Journal of business research, v. 69, n. 2, pp. 897-904.

https://doi.org/10.1016/j.jbusres.2015.07.001

España (2007). “Ley orgánica 3/2007, de 22 de marzo, para la igualdad efectiva de mujeres y hombres”. BOE, n. 71, 23 marzo.

https://www.boe.es/buscar/act.php?id=BOE-A-2007-6115

Etura-Hernández, Dunia; Martín-Jiménez, Virginia; Ballesteros-Herencia, Carlos A. (2019): “La comunidad universitaria, frente a la igualdad de género: un estudio cuantitativo”. Revista latina de comunicación social, pp. 1781-1800. http://www.revistalatinacs.org/074paper/1410/93es.html

European Commission (2018). Online executive summary: Employment and social developments in Europe 2018. https://ec.europa.eu/employment_social/empl_portal/publications/Esde2018/index.html

European Commission (2019a). Índice de la economía y la sociedad digitales (DESI). Informe de país 2019 España. https://bit.ly/2P56Nbe 
European Commission (2019b). Women in digital scoreboard 2019. Spain.

https://bit.ly/380E6Vs

García-González, Aurora; Piñeiro-Otero, Teresa (2011). “Las mujeres, en el ámbito de la producción publicitaria. Estudio del sector publicitario gallego desde una perspectiva de género". Revista latina de comunicación social, n. 66, pp. 505525 . https://doi.org/10.4185/RLCS-66-2011-943-505-525

Grow, Jean M.; Deng, Tao (2014). "Sex segregation in advertising creative departments across the globe". Advertising \& society review, v. 14, n. 4, pp. 14-24. https://doi.org/10.1353/asr.2014.0003

Li, Hairong (2019). "Special section introduction: Artificial intelligence and advertising". Journal of advertising, v. 48, n. 4, pp. 333-337. https://doi.org/10.1080/00913367.2019.1654947

Hernández-Ruiz, Alejandra; Martín-Llaguno, Marta; Martínez-Martínez, Inmaculada-José; García-González, Aurora (2012). "Publicidad y género: actitudes y expectativas laborales de estudiantes de publicidad”. En: Tortosa-Ybáñez, María-Teresa; Álvarez-Teruel, José-Daniel; Pellín-Buades, Neus (coords.). X Jornadas de redes de investigación en docencia universitaria: la participación y el compromiso de la comunidad universitaria. Universidad de Alicante, pp. 2876-2888. ISBN: 9788469528778

http://rua.ua.es/dspace/handle/10045/24277

IAB-Spain (2018). Estudio del mercado laboral en marketing digital. http://bit.ly/2KZduKz

InfoAdex (2018). Estudio de agencias de publicidad y de medios. Madrid: InfoAdex.

InfoAdex (2019). Estudio InfoAdex de la inversión publicitaria en España. Madrid: InfoAdex.

https://www.infoadex.es/home/estudio-infoadex-de-la-inversion-publicitaria-en-espana-2019

INE (2019a). Indicadores demográficos. Datos provisionales 2018. Instituto Nacional de Estadística. https://bit.ly/2Rg/9Zf

INE (2019b). Mujeres con estudios superiores según el número de hijos, nivel de estudios completado y edad. Instituto Nacional de Estadística.

https://bit.ly/37SypJr

Kaufmann-Argueta, Jürg (2017). La transformación digital de la agencia de publicidad. Estudio empírico del caso español. Madrid: Aeacp.

http://bit.ly/2nkpCwM

Kumar, V.; Gupta, Shaphali (2016). "Conceptualizing the evolution and future of advertising”. Journal of advertising, v. 45, n. 3, pp. 302-317.

https://doi.org/10.1080/00913367.2016.1199335

López-García, Xosé; Rodríguez-Vázquez, Ana-Isabel; Pereira-Fariña, Xosé (2017). “Competencias tecnológicas y nuevos perfiles profesionales: desafíos del periodismo actual". Comunicar, v. 25, n . 53, pp. 81-90.

https://doi.org/10.3916/C53-2017-08

Mallia, Karen L.; Windels, Kasey (2011). "Will changing media change the world? An exploratory investigation of the impact of digital advertising on opportunities for creative women". Journal of interactive advertising, v. 11, n. 2, pp. 30-44.

https://doi.org/10.1080/15252019.2011.10722183

Martín-Guart, Ramón; Fernández-Cavia, José (2014). “La publicidad y la agencia de medios frente al cambio en el ecosistema mediático". Cuadernos.info, n. 34, pp. 13-25.

https://doi.org/10.7764/cdi.34.572

Martín-Llaguno, Marta (2007). “La mujer en la industria publicitaria. La segregación vertical en la comunicación comercial: techo de cristal y suelo pegajoso". Zer. Revista de estudios de comunicación, v. 12, n. 22, pp. 429-452.

http://bit.ly/2IL4xel

Martín-Llaguno, Marta (2008). "Radiografía del sector publicitario con enfoque de género". Telos, Cuadernos de Comunicación e Innovación, n. 75, pp. 140-152.

https://telos.fundaciontelefonica.com/archivo/numero075/radiografia-del-sector-publicitario-con-enfoque-de-genero

Martín-Llaguno, Marta; Beléndez-Vázquez, Marina; Hernández-Ruiz, Alejandra (2007). La mujer en las agencias de publicidad. Madrid: AEAP.

http://rua.ua.es/dspace/handle/10045/808 
Ministerio de Industria, Energía y Turismo (2015). Libro blanco para el diseño de las titulaciones universitarias en el marco de la economía digital. Madrid: Minetur.

http://bit.ly/2m4PooC

Monge-Benito, Sergio; Etxebarria-Gangoiti, Joseba-Andoni (2017). “Competencias más valoradas por los profesionales de la publicidad de la Comunidad Autónoma Vasca. Comparación 2008-2016". Communication \& society, v.30, n. 2, pp. 97-111.

http://hdl.handle.net/10171/43908

Moreno, Ángeles; Fuentes, Cristina; Khalil, Nadia (2018). Informe GenderCom. Brechas y oportunidades de género en la profesión de gestión de la Comunicación en España. Madrid: Dircom. ISBN: 9788409076673

http://www.dircom.org/actualidad-dircom/item/9424-informe-gendercom-brechas-y-oportunidades-de-genero-en-laprofesion-de-gestion-de-la-comunicacion-en-espana

Ng, Eddy S.; Parry, Emma (2016). "Multigenerational research in human resource management”. In: Buckley, M. Ronald; Halbesleben, Jonathon R. B.; Wheeler, Anthony R. (eds.). Research in personnel and human resources management. Emerald Group Publishing Limited, pp. 1-41. ISBN: 9781786352644

https://doi.org/10.1108/S0742-730120160000034008

Núñez, Patricia; García, Alberto; Abuín, Natalia (2013). "Profesionales digitales en publicidad y comunicación. Una aproximación a las necesidades del mercado laboral”. CIC. Cuadernos de información y comunicación, v. 18, pp. 177187.

https://doi.org/10.5209/rev_CIYC.2013.v18.41723

Papí-Gálvez, Natalia (2015). “Nuevos medios y empresas innovadoras. El caso de las agencias de medios”. El profesional de la información, v. 24, n. 3, pp. 301-309.

https://doi.org/10.3145/epi.2015.may.10

Perlado-Lamo-de-Espinosa, Marta; Papí-Gálvez, Natalia; Bergaz-Portolés, María (2019). “Del planificador de medios al experto en medios: el efecto digital en la publicidad". Comunicar, v. 27, n. 59, pp. 105-114.

https://doi.org/10.3916/C59-2019-10

Pueyo-Ayhan, Natalia (2010). "Sex structure of occupations in advertising industry: Where are the female ad practitioners?". Observatorio (OBS*), v. 4, n. 3, pp. 243-267.

http://obs.obercom.pt/index.php/obs/article/view/416

Puy-Rodríguez, Ana (coord.) (2017). Científicas en cifras 2017. Estadísticas e indicadores de la (des)igualdad de género en la formación y profesión científica. Madrid: Ministerio de Ciencia, Innovación y Universidades.

https://bit.ly/2Dx5ZGT

Scopen (2018). Informe de resultados. Media Agency.

http://bit.ly/2ClH6Od

Scopen (2019). The partners book. Madrid: Scopen. https://scopen.com/en/section/research

Soria-Ibáñez, María-del-Mar; Gómez-Nieto, Begoña (2017). “Análisis del rol profesional de mujeres y hombres en las agencias de publicidad españolas. Percepciones e integración de igualdad de oportunidades". Sphera publica, v. 2, n. 17, pp. 167-193.

http://sphera.ucam.edu/index.php/sphera-01/article/view/313

United Nations (1995). Beijing declaration and platform for action.

https://bit.ly/2XugoO7

Ventura, Rafael; Roca-Cuberes, Carles; Corral-Rodríguez, Andrea (2018). “Comunicación digital interactiva: valoración de profesionales, docentes y estudiantes del área de la comunicación sobre las competencias académicas y los perfiles profesionales". Revista latina de comunicación social, n. 73, pp. 331-351.

https://doi.org/10.4185/RLCS-2018-1258 